\title{
Excess worker turnover and fixed-term contracts: Causal evidence in a two-tier system*
}

\author{
Mário Centeno \\ Banco de Portugal \& ISEG - U. Técnica \& IZA \\ mcenteno@bportugal.pt
}

\author{
Álvaro A. Novo \\ Banco de Portugal \& U. Lusófona \& IZA \\ anovo@bportugal.pt
}

February 28, 2012

\begin{abstract}
Portuguese firms engage in intense reallocation, most employers simultaneously hire and separate from workers, resulting in high excess worker turnover flows. These flows are constrained by the employment protection gap between open-ended and fixed-term contracts. We explore a reform that increased the employment protection of open-ended contracts and generated a quasi-experiment. The causal evidence points to an increase in the share and in the excess turnover of fixed-term contracts in treated firms. The excess turnover of open-ended contracts remained unchanged. This result is consistent with a high degree of substitution between open-ended and fixed-term contracts. At the firm level, we also show that excess turnover is quite heterogeneous and quantify its association with firm, match, and worker characteristics.
\end{abstract}

Keywords: Excess worker turnover; Two-tier systems; Quasi-experiment; Fixed-term contracts

JEL Codes: J21; J23; J63.

\footnotetext{
*We thank Francine D. Blau and Paolo Naticchioni for the discussions and the comments made by participants at the 2011 Banco de Portugal Labor Workshop, Gaia, and at the 52nd SIE Meeting, Rome. We also thank the editors Katharine Abraham and Ian Walker and the three anonymous referees. We would like to thank Jason Farberman for making available to us the U.S. data and for a fruitful discussion of the paper and the Instituto de Informática of the Portuguese Social Security Institute for making the data available to us. We acknowledge the financial support provided by FCT's grant PTDC/EGE-ECO/112177/2009. Opinions expressed herein do not necessarily reflect the views of the Banco de Portugal. Any errors are the responsibility of the authors.
} 


\section{Introduction}

The simultaneity of separations and hirings at the firm level generates worker turnover in excess of what would be strictly necessary for a firm to achieve a given employment level. The theoretical basis for the existence of these simultaneous flows in the same firm rests on the existence of shocks (uncertainty) to the allocation of labor broadly defined (Jovanovic 1979, Davis and Haltiwanger 1990, Gibbons and Katz 1991).

This paper contributes to the characterization of excess worker turnover at the firm level within a two-tier system, an institutional framework in which protected open-ended contracts coexist with more flexible fixed-term arrangements. In the last decades, twotier reforms characterized the development of labor market regulations in most European countries. Rather than flexing the rules governing open-ended contracts, labor market reforms increased the protection gap between incumbents (on open-ended contracts) and entry jobs (mostly on fixed-term contracts). In 2004, a reform of the Portuguese labor code repeated the same formula. It increased the protection of open-ended employment for firms with 11 to 20 workers, but left it unchanged for all other firms and contracts. We explore this change as a quasi-experiment.

The short nature of fixed-term matches can be associated with worker turnover at the firm level. In Abowd, Corbel and Kramarz (1999) and Boeri (2010) matching models, fixed-term contracts play an important role in the initial stages of the matching process. The fixed-term contract is interpreted as an investment that, if successful, may be converted into an open-ended contract. These models predict that a larger protection gap between open-ended and fixed-term contracts is associated with a larger share of fixed-term contracts in employment and with a smaller conversion rate of fixed-term to open-ended contracts. This implies that the number of workers hired until a vacancy is filled permanently will be larger, resulting in higher turnover for fixed-term contracts and lower job destruction for open-ended contracts.

We use two administrative matched employee-employer datasets covering all private sector jobs and show that worker flow rates in the Portuguese labor market largely exceed the rates of job creation and destruction. The ratio of the worker hiring and job creation rates equals 2 - for every job created in the economy there are two hirings; the same is 
true for the ratio between worker separation and job destruction rates. Davis, Faberman and Haltiwanger (2006) report similar ratios for the U.S., as does Bassanini (2010) for a large number of OECD countries.

But how is this employment variability achieved in Portuguese firms? To answer this question, we resorted to the quasi-experimental setting generated by the 2004 legislative reform. This allowed us to identify causal relationships between the employment protection gap of open-ended and fixed-term contracts and two important labor market indicators: the composition of employment and the level of excess worker turnover. Difference-indifferences estimates indicate that treated firms, with 11 to 20 workers, increased the share of fixed-term contracts (1.6 percentage points), while overall excess worker turnover remained unchanged, relatively to the control firms with 21 to 100 workers. More interestingly in the context of two-tier reforms, we obtained a significant increase in excess turnover of fixed-term contracts in treated firms (1.3 percentage points), whereas excess turnover for open-ended workers remained unchanged. This can be interpreted as a sign of substitutability between open-ended and fixed-term positions in Portuguese firms, a result also found by Cappellari, Dell'Aringa and Leonardi (2011) for Italy.

In the spirit of Burgess, Lane and Stevens (2001), we also quantified the contribution of worker, firm, and match characteristics to the excess worker turnover at the firm level. The results are consistent with other findings in the literature and, in particular, confirm that fixed-term contracts are positively associated with excess worker turnover. The substitution effect suggested in the quasi-experimental setting was confirmed in this analysis; a larger share of fixed-term contracts crowded out turnover among open-ended contracts, and directed it towards fixed-term contracts.

Our analysis contributes to the growing literature on two-tier labor markets (Bentolila, Cahuc, Dolado and Le Barbanchon 2010, Boeri 2010, Cahuc, Charlot and Malherbet 2012), providing causal evidence of the role played by the interaction between open-ended and flexible contracts on the ability of firms to achieve a desired level of excess worker turnover. 


\section{Two-tier labor market: Reform and theory}

The labor market in Portugal is an extreme case of a two-tier system. In this section, we provide an overview of its characteristics, along with a description of a reform that provides a quasi-experimental setting to analyze the impact of an increase in the protection gap between open-ended and fixed-term contracts. We describe theoretical models that help us understand the functioning of two-tier labor markets.

\subsection{The 2004 reform: More protection for open-ended contracts}

The Portuguese labor market evolved to a two-tier system in which different types of contracts are offered concurrently: fixed-term and open-ended contracts. According to the OECD employment protection legislation indicator, Portugal has one of the largest protection gaps between these two type of contracts. Furthermore, there is a widespread usage of fixed-term contracts - in 2002, they represented almost $20 \%$ of total salaried employment, increasing to more than $27 \%$ in 2008 . With these features, the Portuguese two-tier system is well suited to analyze and quantify the relationship between excess worker turnover and the employment protection gap.

Fixed-term contracts were first introduced in 1976 and have been revised several times since. They are a legal instrument for all levels of qualifications and most tasks. The severance payment of open-ended contracts is slightly larger than for fixed-term contracts. ${ }^{1}$ But the largest difference between the two contracts resides in the procedural costs to terminate a match. These are absent at the expiration of fixed-term contracts, but are rather significant for permanent positions.

Firing a worker on an open-ended contract involves more than just paying a compensation. In Portugal, procedural costs are non-negligible. These include written procedures and witnesses interviews involving the workers council and, if the worker is a union delegate, the union itself. Altogether, the procedures extend the dismissal process substantially, typically 2 months, involving legal counselors and administrative costs.

Up to 2004, the law exempted firms with less than 20 workers from these legal proce-

\footnotetext{
${ }^{1}$ At the expiration of a fixed-term contract, the worker receives a severance payment equal to 3 days for each month of employment ( 2 days if the employment relationship lasted less than 1 year). For permanent contracts the severance payment is set in court, between 15 and 45 days for each year of seniority (often 30 days), with a minimum of 90 days.
} 
dures. A reform of the labor code in 2004 changed this threshold to 10 workers (Decreto-Lei 99/2003). Therefore, the reform generated a quasi-experiment in which the protection gap between open-ended and fixed-term contracts widened for a subset of firms, but remained the same for all other firms. To some extent this reform undid the 1989 reform analyzed in Martins (2009).

In this setting, firms with 11 to 20 workers constitute the treatment group; firms with 21 to 100 workers, a subset of those not affected by the reform, constitute the control group. The firm-size restrictions follow, among others, Burgess et al. (2001), Kugler and Pica (2008), and Martins (2009). We test extensively the sensitivity of our results to the specific choice of the treatment and control groups.

\subsection{The theoretical framework of two-tier systems}

Excess worker turnover can arise from the reevaluation of job match quality. This process of mobility is the result of an investment decision where the match is an "experience good"; as in Jovanovic (1979), the only way to determine its quality is to form the match and "experience it". As the firm and the worker learn about the match quality, they assess the costs and benefits of changing labor market partner. If either side decides to change partner, but not to change labor market state (the worker supplies labor; the firm keeps the same employment level), they will generate excess worker turnover. These decisions vary from firm to firm, as a result of the degree of heterogeneity of firms' personnel policies and the evolution of the match value. For instance, some firms have higher turnover costs; some skills are easier to observe and, therefore, to evaluate prior to the match formation; and the frequency of technological changes varies across firms. All these factors affect the optimal degree of excess worker turnover, which in some cases may lead several firms to opt for a zero excess worker turnover.

The perception in several developed countries of a strong protection of open-ended contracts led to the introduction of reforms aimed at increasing flexibility in the labor market. As surveyed in Boeri (2010), the most common reform was the introduction of fixed-term contracts, with lower dismissal costs (both procedural and financial). These reforms left unchanged the regulation of open-ended contracts, which generated two-tier systems and affected the level and composition of job and worker flows. 
The theoretical analysis of two-tier systems goes back to the work of Abowd et al. (1999), who in turn extend the work of Davis and Haltiwanger (1990) to include the forces that may affect the mobility of workers between jobs, featuring a specific role for fixedterm contracts. In their model, the worker is hired initially under a fixed-term contract, which is interpreted as a period of investment required to generate a high-productivity job. The worker mobility induced by fixed-term contracts reflects the uncertainty in the success of the initial match-specific investment. The number of fixed-term appointments required to generate a productive job is uncertain. It may involve hiring and separation from several workers before a permanent vacancy is filled. However optimal, this chain of matches generates excess worker turnover at the firm level.

The Boeri (2010) model follows a similar approach. As in Abowd et al. (1999), all entrylevel jobs are fixed-term contracts and the rate of conversion into open-ended contracts depends on the protection gap between the two contract types. Boeri (2010) predicts that an increase in the employment protection for incumbents (under open-ended contracts) decreases the conversion of temporary jobs into permanent ones. This implies an increase in the share of fixed-term contracts for entry-level jobs and in their turnover rates. This increase in the protection gap will also imply a reduction in the job loss rate of openended contracts, but will have an ambiguous impact on their excess worker turnover, as accessions into permanent jobs are also reduced. More recently, Bentolila et al. (2010) and Cahuc et al. (2012) model two-tier labor markets and calibrate them to the French and Spanish labor markets. They show that a larger protection gap leads to a more frequent destruction of matches under fixed-term contracts, with similar impacts on excess worker turnover.

In the models above, the change in excess worker turnover for each type of contract in response to an increase in the employment protection of open-ended contracts rests on the assumption of substitutability between them. If they are poor substitutes, then excess worker turnover of fixed-term contracts may not change.

These models provide a guide to interpret the relationships between excess worker turnover and the employment protection gap. The key issue in labor markets in which substitutable contracts are offered concurrently is not the optimal level of excess worker turnover at the firm level, but the role played by each type of contract in the ability of firms 
to reach their desired level of worker rotation. Our paper quantifies these relationships.

\section{Aggregate job, worker, and excess worker turnover flows}

We start our analysis by computing aggregate measures of job and worker flows in the Portuguese economy and compare them with stylized facts known for other economies. We follow Abowd et al. (1999) and explore possible sources of heterogeneity at the firm level arising from differences in size and type of employment growth. We base this analysis of job and worker flows on Social Security administrative records.

\subsection{Job and worker flow concepts}

Our analysis of labor market flows is based on the standard definitions laid down in Davis, Haltiwanger and Schuh (1996). For a given firm, the year-to-year job creation and destruction rates are, respectively,

$$
C_{t}=\max \left\{0, \frac{\left(X_{t}-X_{t-1}\right)}{\left(X_{t}+X_{t-1}\right) / 2}\right\} \quad \text { and } \quad D_{t}=\max \left\{0, \frac{\left(X_{t-1}-X_{t}\right)}{\left(X_{t}+X_{t-1}\right) / 2}\right\}
$$

where $X_{t}$ is the number of employees in (October of) year $t$.

The hirings in year $t, H_{t}$, are defined as the number of workers in a firm at time $t$ that were not employed in that firm at $t-1$. The separations in year $t, S_{t}$, are equal to the number of workers in a firm at time $t-1$ that are not employed in that firm at $t$. The year-to-year rates are

$$
H R_{t}=\frac{H_{t}}{\left(X_{t}+X_{t-1}\right) / 2} \quad \operatorname{and} S R_{t}=\frac{S_{t}}{\left(X_{t}+X_{t-1}\right) / 2}
$$

The rate of net employment change (NEC) is equal to the difference between the hiring and separation rates, $N E C_{t}=H R_{t}-S R_{t}$.

The rate of excess worker turnover is given by $E W T_{t}=H R_{t}+S R_{t}-\left|N E C_{t}\right|$. Burgess, Lane and Stevens (2000) refer to this concept as churning. Excess worker turnover is the key concept in this study. Intuitively, it corresponds to worker flows in excess of those strictly necessary to achieve a given level of employment.

We apply also these conventional definitions to the groups of workers defined by con- 
tract type. We considered as separations from open-ended contracts all workers who had an open-ended contract in $t-1$, but are no longer with the firm in year $t$; similarly, hirings are defined as all workers with an open-ended contract in $t$ who were not in the firm in year $t-1$. The rate of excess worker turnover for open-ended contracts is obtained by dividing these flows by the average number of open-ended contracts in the firm in the two periods.

The same computation is made with respect to fixed-term contracts. One note must be made, however, because some fixed-term contracts may be converted into open-ended contracts. We do not consider these conversions either as separations from fixed-term contracts, or as hirings into open-ended contracts. Thus, hirings and separations imply always a flow in or out of the firm.

Note that total excess worker turnover is not equal to the sum of excess worker turnover by contract type. A simple example makes this point clear. Consider a firm with 50 workers that decides to replace 10 open-ended jobs with 10 workers under fixed-term contracts. This will generate excess worker turnover because the firm engages in hirings and separations simultaneously. In particular, it results in an excess turnover rate of 0.4. However, for each type of contract the turnover is zero because the increase in level of fixedterm contracts equals the number of hirings and the reduction in open-ended contracts equals the number of separations.

\subsection{Aggregate flows}

We use the Social Security Records database to compute annual job and worker flows. The database is a matched employer-employee census of private and public sector employment (excluding only firms with individual pension funds and the civil servants covered by the general government social security system). The nature of the information, self-declared wages subject to mandatory contributions to the Portuguese Social Security system, makes the data a unique and reliable source of information on labor market developments. The data cover the period from January 2000 to December 2009.

Table 1 shows the 2000-2009 average annual rates of job and worker flows for all firms in the economy. In Portugal, during this period, job creation averaged $12.7 \%$ and the destruction rate $11.9 \%$. But the process of job creation and destruction involves larger 
worker flows; at about 25\%, hiring and separation rates are twice the rates of job flows. Firms expanding one employment position hire two workers and firms contracting one employment position separate from two workers (columns (5) and (6)), a rough measure of excess worker turnover.

[TABLE 1 (see page 21)]

We compare the flow rates of Portugal with the U.S., using data from the Job Openings and Labor Turnover Survey (JOLTS) for worker flows and the Business Employment Dynamics (BED) for job flows (Davis, Faberman, Haltiwanger and Rucker 2010). ${ }^{2}$ From 2000 to 2006, average labor market flows in Portugal were about $90 \%$ those in the U.S. (Table 1). However, the hiring-to-job-creation and separation-to-job-destruction ratios are equal in both countries. This means that the cross-country differences in job flows are similar to the cross-country differences in worker flows. Albæk and Sorensen (1998) report similar ratios for Denmark from 1980 to 1990 for the manufacturing sector and also Bassanini (2010) for a large number of OECD countries, using comparable datasets.

The phenomenon of excess worker turnover is more heterogeneous than reflected in the aggregated data. Table 2 separates firms according to their type of employment growth in two consecutive periods. We consider three groups of firms: (i) with net job creation; (ii) with net job destruction; and (iii) with zero net job creation, which we refer to as stable employment. On average, for the overall economy, the employment level in expanding firms is similar to the one in contracting firms, each representing about $41.5 \%$ of total employment. The remaining $17 \%$ of salaried workers are in firms that did not change their employment level.

[TABLE 2 (see page 21)]

On average, the excess worker turnover rate for firms increasing their employment level is $32 \%$, about one-third larger than for firms decreasing the size of their workforce, $24 \%$.

\footnotetext{
${ }^{2}$ The comparison of job and worker flows across countries is hindered, among other things, by the protocol used to collect the data (administrative data vs specific business surveys), the level of coverage (census vs. sample of specific parts of the population, for example large firms), and the sectoral composition of each country employment. The BED data are based on a census of private sector establishments, and the adjusted JOLTS data from Davis et al. (2010) approximates the firm demography in BED (note that the original JOLTS data do not cover new firms, and the sample design does not allow for a treatment of exiting firms). These adjustments make the U.S. flows more comparable with the ones obtained for Portugal using Social Security data. We thank Jason Faberman for making available the comparable JOLTS data.
} 
The larger churning of workers by expanding firms is in line with the results obtained for a census of Maryland firms by Burgess et al. (2001) and with the behavior of French firms in Abowd et al. (1999).

The magnitude and composition of job and worker flows is highly correlated with the firm size (Davis et al. 1996). To analyze this relationship, Table 2 splits the firms into 6 size bins. Excess worker turnover increases with firm size, as measured by the average number of workers, except for stable firms. Intuitively, small firms expanding employment rely more on the hiring of workers, whereas those shedding jobs rely mainly on the separation of workers. In contrast, larger firms have a wider scope to churn workers, engaging actively on worker replacements while adjusting employment. In our data, larger firms expanding employment have a rate of excess turnover of $43.5 \%$, which compares with $23 \%$ for small firms. Firms contracting employment have lower excess worker turnover rates, but larger firms still report higher turnover. ${ }^{3}$

Finally, we note the similar pattern in excess worker turnover among firms in the size range used in the quasi-experiment, namely, those with 10 to 100 workers. Choosing smaller or larger firms would result in less homogeneous groups.

\section{Flows, match duration and type of contract}

The variability of employment adjustment in Portuguese firms does not differ from that observed in other countries. The high numbers of flows and excessive worker turnover do not mean that most workers rotate between jobs, as they are compatible with the prevalence of long-term employment (Hall 1982, Ureta 1992). However, this requires enough heterogeneity in hiring and separation rates across workers, which can be accomplished by placing the burden of the high turnover on fixed-term contracts.

Due to the focus on the relationship between worker turnover and the type of contract, we have to resort to a different dataset, Quadros de Pessoal, where the information on the type of contract is available from 2002. Quadros de Pessoal have been extensively used in the microeconomic analysis of employment in Portugal (Cabral and Mata 2003). It is an annual administrative employer-employee data source. On average, from 2002 to 2008, it

\footnotetext{
${ }^{3}$ A detailed analysis by firm size and other data frequencies can be found in Centeno and Novo (2011).
} 
reports information for 2.4 million salaried workers per year employed by 325,000 firms. Its coverage is similar to the Social Security dataset and the aggregate flows in the two datasets are about the same (Centeno, Machado and Novo 2008).

There is heterogeneity in hiring and separation rates by type of contract and firm employment growth (Table 3). The share of fixed-term contracts is larger in firms increasing employment (28.9\% of employment) than in firms decreasing employment (20.5\% of employment). However, fixed-term contracts are the most important port-of-entry into these two types of firms; $54 \%$ of all accessions in expanding firms and $53 \%$ for firms reducing their employment level. Around $40 \%$ of all exits come from the separation of workers under fixed-term contracts; this share is larger for expanding firms, around 47\%, than for shrinking firms, where only $37 \%$ of all exits are from workers under fixed-term contracts.

[TABLE 3 (see page 22)]

Table 3 also shows that expanding firms rely more on hirings under fixed-term contract to expand their operations. Of a net growth rate of $21.5 \%, 12.7$ percentage points correspond to hirings on fixed-term contracts ( $60 \%$ of net employment gains). Conversely, contracting firms separate from a much larger share of permanent workers. Almost three quarters of the net employment losses of $18.1 \%$ result from a reduction in the level of permanent positions (13.1 percentage points).

An alternative measure of worker turnover is the duration of matches. We compute match survival probabilities from a base year by contract type. Table 4 presents the share of workers that preserve the 2002 match in the following years (from 2003 up to 2008), regardless of the number of years of tenure (column (1)). The results show that there is a stable core of employment in Portuguese firms - around $40 \%$ of the workers are still employed by the same firm after six years. This figure is slightly smaller than in Burgess et al. (2000) for the U.S. (42.5\% for manufacturing and $47.3 \%$ for non-manufacturing). We repeat the same exercise for workers with a fixed-term contract in 2002. As expected, they had a smaller probability of remaining in the firm. In 2003, $40 \%$ were still on a fixed-term contract (column (2)) and 14\% had been converted to a open-ended contract (column (3)). However, in 2008, only one quarter were still in the same firm, the majority with a permanent job, $19 \%$, but $6 \%$ remained under a fixed-term contract. In other words, 
$75 \%$ separated from the firm.

[TABLE 4 (see page 22)]

\section{Quasi-experimental evidence}

Hitherto, we have presented a set of stylized facts characterizing the two-tier nature of the Portuguese labor market. In this section, we take advantage of the legislative reform described in Section 2.1 to gather quasi-experimental evidence. The increase in the degree of employment protection that affected open-ended contracts in a subset of firms is explored to capture the differentiated impact on excess worker turnover by type of contract - openended and fixed-term, as well as on the share of fixed-term contracts.

It should be recalled that the reform increased the legal requirements needed to justify a fair dismissal for those on open-ended contracts and applied only to firms with 11 to 20 workers; similar requirements were already in place in 2004 for firms with more than 20 workers. Therefore, these larger firms were not affected by the new legislation. For each period, we consider as treatment units the firms with 11 to 20 workers and as control units firms with 21 to 100 workers. Later, we assess the sensitivity of the results to changes in the definition of the treatment and control groups.

Table A1, in the Appendix, presents summary statistics for the sample of treatment and control firms taken from Quadros de Pessoal. There are a total of 45,876 firms, resulting in an unbalanced panel with 181,131 observations (year $\times$ firm pairs). These firms employed an average of 610,000 workers each year. In the before period, which corresponds to 2003, there were 14,170 treatment observations and 11,877 control observations. In the after period, 2004 to 2008 , there were 81,439 treatment observations and 73,645 control observations. The average share of fixed-term contracts was $28.2 \%$. Firms churned, on average, $24.6 \%$ of their workforce in annual terms. The churning of fixed-term workers was $34.7 \%$, clearly larger than the churning of workers on open-ended contracts, $12.4 \%$.

\subsection{Match duration: Prima facie causal evidence}

To get prima facie causal evidence of the impact of the 2004 two-tier labor market reform on the structure of worker turnover, we resort to the match duration statistics used above. 
Table 5 presents two-year match survival probabilities for treatment and control firms. We compute these probabilities in the pre- and post-reform periods, which have as base years 2002 and 2004, respectively. The choice of the two-year survival is determined by the short pre-reform observation window. However, this shortcoming is mitigated by the fact that the conversion rates of fixed-term into open-ended contracts stabilize after the second year (Table 4).

[TABLE 5 (see page 23)]

The resulting unconditional difference-in-differences estimates of Table 5 are in line with the predictions of the two-tier models. Faced with higher procedural firing costs for open-ended contracts, treated firms increased the share of workers still on a fixed-term contract by 2.5 percentage points (column (2)). More importantly from the point of view of worker turnover, firms also reduced the conversion rate of fixed-term into open-ended contracts by 1.9 percentage points (column (3)). Overall, the increase in employment protection led to a slightly higher stability of employment, 0.7 percentage points (column $(1))$.

\subsection{Difference-in-differences: More stringent employment protection}

We explore the quasi-experiment to obtain causal evidence of the impact of employment protection legislation on the composition of employment and the level of excess worker turnover. To identify the causal average treatment effect on the treated we use a standard conditional difference-in-differences model:

$$
y_{i t}=\psi_{1} \text { Treat }_{i t}+\psi_{2} \text { After }_{i t}+\psi_{3} \text { After }_{i t} \text { Treat }_{i t}+X_{i t} \beta+\varepsilon_{i t},
$$

where $y_{i t}$ is either the share of fixed-term contracts or the level of excess worker turnover in firm $i$ in period $t$. After $i t$ is a dummy variable for the period after 2003. The treatment indicator, Treat ${ }_{i t}$, is defined for each period $t$, and equals 1 for the treatment group (firms with 11-20 workers) and 0 for the control group (firms with 21-100 workers). Consequently, the interaction term, After $i t \times$ Treat $_{i t}$, identifies the impact of the policy change. A set of firm, match, and worker characteristics, such as, the firm size, the average (log) base 
wage, the educational level and average age of the firm's workforce are included in $X_{i t}$; a comprehensive list of the variables used is presented in the note to Table 6. We opt to estimate this equation with the fixed-effects estimator, for which it is assumed that the error term $\varepsilon_{i t}=\alpha_{i}+u_{i t}$, where the unobserved component $\alpha_{i}$ is orthogonal to $X_{i t}$ and $u_{i t}$ is the idiosyncratic error.

[TABLE 6 (see page 24)]

We start by studying the impact that a more stringent employment protection legislation had on the share of fixed-term contracts. Churning is a natural process that involves simultaneous hirings and separations, which are more costly for workers in open-ended contracts. Faced with an increase in the firing costs of these contracts, firms may have opted for increasing the share of fixed-term contracts. We test this hypothesis in the quasi-experimental setting, expecting $\psi_{3}$ to be positive. Column (1) of Table 6 reports the average treatment effect on the share of fixed-term contracts for the treated firms. The new legislation caused treated firms to increase their usage of fixed-term contracts by 1.6 percentage points.

In the mind of the legislator, there may have only been the intention of reducing churning by making it more expensive to justify fair dismissals. We have, however, seen that firms switched towards fixed-term contracts. But did they also use this type of contract to churn workers? In columns (2) and (3), we test how the new legislation affected the rate of excess worker turnover by type of contract. Churning among workers on fixedterm contracts in treated firms increased 1.3 percentage points, while no significant impact is observed among open-ended contracts (there is, if anything, a reduction). These results are aligned with the models' predictions. They corroborate the shift towards an extended usage of fixed-term contracts and the fact that there is a strong substitution between the two type of workers. This substitutability is in line with the results found in Cappellari et al. (2011) for Italian firms, providing additional support for such assumption in the models.

Finally, in column (4), we report the results of the difference-in-differences estimation for total excess worker turnover. The estimate indicates that the more stringent dismissals regulation did not change the level of excess worker turnover for treated firms. Although 
Martins (2009) did not study turnover, he also did not find any impact on total job and worker flows of a reduction in employment protection for Portuguese firms.

\subsection{Endogeneity of treatment responses}

The definition of treatment and control units based on the size of the firm opens the possibility for firms to self-select into the treatment and control groups in response to the policy. The use of the fixed effects estimator should go a long way to obviate issues of endogeneity in the regressors (Lee 2005). Nonetheless, in columns (1)-(6) of Table 7, we redefine the treatment and control groups following, among others, Kugler and Pica (2008) and Martins (2009). First, we set the treatment status in the before period and keep it unchanged in the after period, even if firms changed size (columns (1)-(3)). Second, we consider only firms that never changed status during the entire observation window (columns (4)-(6)).

[TABLE 7 (see page 25)]

Both definitions are fraught with shortcomings, arising from the fact that they are selected samples of the targeted population. However, our point estimates of the causal effect are robust to these new definitions. In the case of the impact on the share of fixedterm contracts, the new estimates suggest a slightly larger impact with a treatment effect on the treated of around 2 percentage points (columns (1) and (4)), which compare with the previous point estimate of 1.6 percentage points. In terms of excess worker turnover, we still obtain only significant impacts on the turnover of fixed-term contracts. In column (2), where the treatment status is set in the before period, the point estimate is the same as initially, 1.3 percentage points. In column (5), for the sample with firms that have the same treatment status in the entire period, the impact stands at 2.1 percentage points.

An additional concern arises from the behavior of firms close to the size thresholds, as they may strategically choose a smaller size to minimize procedural firing costs. To address this issue, we remove from the data firms clustered around each period's threshold (columns (7)-(9)). In particular, in the before period, with a 20-worker threshold, firms with 18-25 workers are not considered and, in the after period, with a 10-worker threshold, firms with 11 or 12 workers are excluded. Again, all point estimates are in the range 
reported hitherto. Fixed-term contracts were more used, 1.8 percentage points, churning of fixed-term contracts increased 1.3 percentage points, and there is no treatment impact on the turnover of open-ended contracts.

Taken together, these results allow us to draw some conclusions on the nature of the Portuguese two-tier labor market. Increasing the firing costs of open-ended contracts caused firms to optimally increase the share of workers on fixed-term contracts (1.6 to 2.1 percentage points); firms re-optimized their personnel policies against future dismissal costs due to the shielded nature of incumbents under open-ended contracts. We also saw an increase in churning among fixed-term contracts (1.3 to 2.1 percentage points), while the additional protection shielded open-ended contracts from churning (negative, but nonsignificant). The distinct impacts on the two types of contracts is suggestive of a strong substitutability among workers under different contracts. Increasing the protection gap between contract types in a two-tier system caused, as predicted theoretically, an increase in the adjustment burden shared by those on the more flexible contracts.

\section{$6 \quad$ Regression analysis}

We have already presented the main characteristics of the Portuguese labor market flows and causal evidence on the relationship between firing costs of open-ended contracts in a two-tier system and the level of excess worker turnover. Now, we quantify the relationship between the rate of excess worker turnover and a set of covariates capturing firm, match, and worker characteristics. This type of quantification is still missing by and large in the literature. Our work, therefore, will contribute to a better understanding of worker turnover in view of particular labor market characteristics. We explore a panel of firms taken from Quadros de Pessoal and estimate firm fixed effects models (Table 8). ${ }^{4}$

\section{[TABLE 8 (see page 25)]}

\footnotetext{
${ }^{4}$ In the panel, around one third of the observations (pairs year $\times$ firm) have zero excess worker turnover. From an econometric point of view, this mass point might be more appropriately addressed with tobit models. In a previous version of the paper, we also estimated tobit models. The need to retrieve the marginal effect on the expected value of the observed variable (as opposed to the latent variable) requires a parametric estimation method. Unfortunately, no such method is available for fixed-effects, only randomeffects; the fixed effects estimator developed in Honoré (1993) is fully non-parametric, limiting its usefulness in our setting. However, because there are no substantive quantitative differences between the randomeffects tobit model and the standard linear fixed-effects, we will follow the literature (Burgess et al. 2001) and stick with the latter, which has better properties to handle obvious concerns with the endogeneity of some of the regressors.
} 
In the dichotomy of two-tier labor markets, with a high substitutability between contract types, the most interesting association is the one established between (the share of) fixed-term contracts and the level of excess worker turnover. Our regression setup shows that fixed-term contracts have distinct impacts on the rates of excess worker turnover computed by contract type. An increase of 10 percentage points in fixed-term contracts (about one-third standard deviation) raises the turnover of workers on fixed-term contracts by 2.69 percentage points, but it decreases the turnover of workers on open-ended contracts by 1.89 percentage points. Again, we observe a substitutability of the two types of workers, which we had already hinted at in the quasi-experimental setting. Although the parts do not add up to the whole, in column (3), we see that more workers on fixedterm contracts result in higher levels of overall excess worker turnover. An increase of 10 percentage points in the share of fixed-term contracts is associated with an increase in excess worker turnover of 0.72 percentage points.

To help in grasping the magnitude of this impact, Table A2 presents the impacts of other covariates on the level of turnover. Overall, the associations of firm, worker, and match characteristics with excess worker turnover by type of contract are in line with results in the empirical job search literature (Topel and Ward 1992, Burgess et al. 2001, Haltiwanger, Jarmin and Miranda 2010).

\section{Conclusions}

The literature on job and worker flows has established a set of stylized facts common across labor markets. Most notably, filling a vacancy requires the hiring and separation of more than one worker. Our analysis of labor market flows in the Portuguese economy adheres to these stylized facts. The personnel policies of Portuguese firms, however conditioned by the perceived rigid labor code, are conducive to an intense reallocation of workers.

In the context of two-tier systems, Abowd et al. (1999), Boeri (2010), Bentolila et al. (2010), and Cahuc et al. (2012) highlight the role of fixed-term contracts as an instrument of adjustment in the matching process. Motivated by these theoretical frameworks and the sustained increase in the share of fixed-term contracts registered in the Portuguese economy, we studied in greater detail the determinants of excess worker turnover. 
We tested the predictions of the models in a quasi-experimental setting. We showed that a more stringent protection of workers on open-ended contracts caused an increase in the reliance on fixed-term contracts by treated firms to achieve their desired level of worker turnover. In this context, we also showed that the same reform caused an increase in churning among workers on fixed-term contracts. Both results pointed to the substitutability of workers on the two type of contracts and the increased burden of adjustment placed on the more flexible contracts.

The political economy debate on the reduction of the employment protection gap through the creation of a unique contract, as discussed in Blanchard and Tirole (2008), should not focus on the reduction of excess worker turnover. After all, as motivated by several search models, the stochastic nature of the matching process leads necessarily to a desirable trial process. Our research showed that the virtue of the unique contract would be to spread more uniformly the adjustment costs across all workers, without hindering the formation of long-term productive employment relationships.

\section{References}

Abowd, J., Corbel, P. and Kramarz, F. (1999), 'The entry and exit of workers and the growth of employment: An analysis of French establishments', Review of Economics and Statistics 81(2), 170-187.

Albæk, K. and Sorensen, B. (1998), 'Worker flows and job flows in Danish manufacturing, 1980-91', The Economic Journal 108(451), 1750-1771.

Bassanini, A. (2010), 'Inside the perpetual-motion machine: cross-country comparable evidence on job and worker flows at the industry and firm level', Industrial and Corporate Change 19(6), 2097-2134.

Bentolila, S., Cahuc, P., Dolado, J. and Le Barbanchon, T. (2010), Two-tier labor markets in the Great Recession: France vs. Spain, Discussion paper 5340, IZA.

Blanchard, O. and Tirole, J. (2008), 'The joint design of unemployment insurance and employment protection: A first pass', Journal of the European Economic Association 6(1), 45-77. 
Boeri, T. (2010), Institutional reforms in European labor markets, in O. Ashenfelter and D. Card, eds, 'Handbook of Labor Economics', Vol. 4, North-Holland, Amsterdam, pp. 1173-1236.

Burgess, S., Lane, J. and Stevens, D. (2000), 'Job flows, worker flows, and churning', Journal of Labor Economics 18(3), 473-502.

Burgess, S., Lane, J. and Stevens, D. (2001), 'Churning dynamics: An analysis of hires and separations at the employer level', Labour Economics 8(1), 1-14.

Cabral, L. and Mata, J. (2003), 'On the evolution of the firm size distribution: Facts and theory', American Economic Review 93(4), 1075-1090.

Cahuc, P., Charlot, O. and Malherbet, F. (2012), Explaining the spread of temporary jobs and its impact on labor turnover, mimeo, CREST-ENSAE, École Polytechnique.

Cappellari, L., Dell'Aringa, C. and Leonardi, M. (2011), Temporary employment, job flows and productivity: A tale of two reforms, Working paper 3520, CESifo.

Centeno, M., Machado, C. and Novo, Á. A. (2008), 'The anatomy of employment growth in Portuguese firms', Economic Bulletin, Banco de Portugal Summer, 75-101.

Centeno, M. and Novo, Á. A. (2011), Excess worker turnover and fixed-term contracts: Causal evidence in a two-tier system, Discussion paper 6239, IZA.

Davis, S., Faberman, J., Haltiwanger, J. and Rucker, I. (2010), Adjusted estimates of workers flows and job openings in JOLTS, in K. G. Abraham, J. R. Spletzer and M. Harper, eds, 'Labor in the New Economy', University of Chicago Press, pp. 187-216.

Davis, S., Faberman, R. and Haltiwanger, J. (2006), 'The flow approach to labor markets: New data sources and micro-macro links', The Journal of Economic Perspectives $\mathbf{2 0}(3), 3-26$.

Davis, S. and Haltiwanger, J. (1990), 'Gross job creation and destruction: Microeconomic evidence and macroeconomic implications', NBER Macroeconomics Annual 5, 123-168.

Davis, S., Haltiwanger, J. and Schuh, S. (1996), Job Creation and Destruction, MIT Press. 
Gibbons, R. and Katz, L. (1991), 'Layoffs and lemons', Journal of Labor Economics 9(4), 351-80.

Hall, R. (1982), 'The importance of lifetime jobs in the US economy', American Economic Review 72(4), 716-724.

Haltiwanger, J., Jarmin, R. and Miranda, J. (2010), Who creates jobs? Small vs. large vs. young, Working Paper 16300, NBER.

Honoré, B. (1993), 'Orthogonality conditions for tobit models with fixed effects and lagged dependent variables', Journal of Econometrics 59, 35-61.

Jovanovic, B. (1979), 'Job matching and the theory of turnover', The Journal of Political Economy 87(5), 972 .

Kugler, A. and Pica, G. (2008), 'Effects of employment protection on worker and job flows: Evidence from the 1990 Italian reform', Labour Economics 15(1), 78-95.

Lee, M.-J. (2005), Micro-econometrics for policy, program, and treatment effects, Advanced Texts in Econometrics, Oxford University Press, Oxford.

Martins, P. (2009), 'Dismissals for cause: The difference that just eight paragraphs can make', Journal of Labor Economics 27(2), 257-279.

Topel, R. and Ward, M. (1992), 'Job mobility and the careers of young men', Quarterly Journal of Economics 107, 439-479.

Ureta, M. (1992), 'The importance of lifetime jobs in the US economy, revisited', American Economic Review 82(1), 322-335. 


\section{Tables}

Table 1: Annual job and worker flows in Portugal and the United States

\begin{tabular}{lcccccc}
\hline & $\begin{array}{c}\text { Job } \\
\text { Criation } \\
(1)\end{array}$ & $\begin{array}{c}\text { Hiring } \\
(2)\end{array}$ & $\begin{array}{c}\text { Job } \\
\text { Destruction } \\
(3)\end{array}$ & $\begin{array}{c}\text { Separation } \\
(4)\end{array}$ & $\begin{array}{c}\text { Hiring/ } \\
\text { JC } \\
(5)=(2) /(1)\end{array}$ & $\begin{array}{c}\text { Separation/ } \\
\text { JD }\end{array}$ \\
& 12.7 & 25.2 & 11.9 & 24.5 & 2.0 & 2.1 \\
& 12.8 & 25.4 & 12.0 & 24.7 & 2.0 & 2.1 \\
\hline Portugal (2001-2009) & 14.6 & 28.5 & 13.7 & 28.0 & 2.0 & 2.0 \\
$\begin{array}{l}\text { Portugal (2001-2006) } \\
\text { USA (2001-2006) }\end{array}$ & 0.88 & 0.89 & 0.88 & 0.88 & \\
Ratio PT/USA (2001-2006) & 0 & & \\
& \\
\hline
\end{tabular}

Table 2: Excess worker turnover rates by firm size, 2001-2009

\begin{tabular}{lccc}
\hline Firm size & $\begin{array}{c}\text { Net job creation } \\
(1)\end{array}$ & $\begin{array}{c}\text { Firms with } \\
\text { Net job destruction } \\
(2)\end{array}$ & $\begin{array}{c}\text { Stable employment } \\
(3)\end{array}$ \\
\hline$[1,10]$ & 23.0 & 19.5 & 18.1 \\
{$[11,20]$} & 27.5 & 22.6 & 22.5 \\
{$[21,100]$} & 30.4 & 24.3 & 23.6 \\
{$[101,250]$} & 28.6 & 20.8 & 21.0 \\
{$[251,499]$} & 32.1 & 24.1 & 19.3 \\
+500 & 43.5 & 28.4 & 22.2 \\
Total & 31.5 & 23.6 & 19.6 \\
& & & 489,639 \\
\hline Employment & $1,224,738$ & $1,174,261$ & $2001-2009$
\end{tabular}

Source: Social Security, 2001-2009. The values reported are the 2001-2009 averages. The rates are computed by comparing the employment in the months of October of two consecutive years. Firm size is proxied by the employment size. 
Table 3: Average worker flows by contract type, 2002-2008

\begin{tabular}{lccc}
\hline & \multicolumn{3}{c}{ Firms with } \\
& $\begin{array}{c}\text { Net job creation } \\
(1)\end{array}$ & $\begin{array}{c}\text { Net job destruction } \\
(2)\end{array}$ & $\begin{array}{c}\text { Stable employment } \\
(3)\end{array}$ \\
\hline Hiring rate & 37.2 & 12.3 & 13.4 \\
into open-ended & 17.1 & 5.8 & 8.0 \\
into fixed-term & 20.1 & 6.5 & 5.4 \\
& & & \\
Separation rate & 15.7 & 30.4 & 13.4 \\
of open-ended & 8.3 & 18.9 & 9.1 \\
of fixed-term & 7.4 & 11.5 & 4.3 \\
& & & 0.0 \\
Net growth rate & 21.5 & -18.1 & -1.1 \\
Contribution by & & & 1.1 \\
open-ended & 8.8 & -13.1 & \\
fixed-term & 12.7 & -5.0 & 327,518 \\
Employment & & & $83.5 \%$ \\
open-ended & 734,506 & 733,350 & 64,580 \\
fixed-term & $71.1 \%$ & $79.5 \%$ & $16.5 \%$ \\
\hline
\end{tabular}

Source: Quadros de Pessoal, 2002-2008.

Table 4: Duration of matches by contract type

\begin{tabular}{cccc}
\hline & $\begin{array}{c}\text { Survival rates } \\
\text { of 2002 matches } \\
(1)\end{array}$ & $\begin{array}{c}\text { Fixed-term contract in 2002 } \\
\text { Still fixed-term } \\
(2)\end{array}$ & $\begin{array}{c}\text { Open-ended contract } \\
(3)\end{array}$ \\
\hline 2003 & 70.3 & 41.4 & 14.1 \\
2004 & 58.3 & 22.3 & 19.6 \\
2005 & 53.2 & 13.8 & 22.9 \\
2006 & 46.7 & 9.7 & 22.0 \\
2007 & 42.1 & 7.5 & 20.4 \\
2008 & 38.1 & 5.8 & 19.0 \\
\hline
\end{tabular}

Source: Quadros de Pessoal, 2002-2008.

Notes: (1) Probability that an individual has the same employer in 2003, 2004, .., 2008 as in 2002. (2) Probability that an individual who had a fixed-term contract in 2002 still has a fixedterm contract with the same firm in $2003,2004, \ldots, 2008$. Note that, in 2003, fixed-term contracts could last up to 6 years. (3) Conversion rate, i.e., the probability that an individual who had a fixed-term contract in 2002 has an open-ended contract with the same firm in $2003,2004, \ldots, 2008$. 
Table 5: Duration of matches: Unconditional difference-in-differences

\begin{tabular}{|c|c|c|c|c|c|c|}
\hline & \multirow{2}{*}{\multicolumn{2}{|c|}{$\begin{array}{c}\text { Two-year } \\
\text { survival probability }\end{array}$}} & \multicolumn{4}{|c|}{$\begin{array}{l}\text { Two-year probability } \\
\text { that a fixed-term }\end{array}$} \\
\hline & & & \multicolumn{2}{|c|}{$\begin{array}{c}\text { is still } \\
\text { fixed-term }\end{array}$} & \multicolumn{2}{|c|}{$\begin{array}{l}\text { is converted to } \\
\text { open-ended }\end{array}$} \\
\hline & $\begin{array}{l}\text { Before } \\
\text { (1) }\end{array}$ & $\begin{array}{l}\text { After } \\
\left(1^{\prime}\right)\end{array}$ & $\begin{array}{l}\text { Before } \\
(2)\end{array}$ & $\begin{array}{l}\text { After } \\
\left(2^{\prime}\right)\end{array}$ & $\begin{array}{l}\text { Before } \\
(3)\end{array}$ & $\begin{array}{c}\text { After } \\
\left(3^{\prime}\right)\end{array}$ \\
\hline Treatment $(\mathrm{T})$ & 54.6 & 59.4 & 22.0 & 28.9 & 18.0 & 15.8 \\
\hline Control (C) & 58.9 & 63.1 & 24.8 & 29.2 & 19.4 & 19.0 \\
\hline Differences $(\mathrm{T}-\mathrm{C})$ & -4.3 & -3.7 & -2.9 & -0.4 & -1.3 & -3.2 \\
\hline Difference-in-differences & \multicolumn{2}{|c|}{$\begin{array}{c}0.7 \\
(0.164)\end{array}$} & \multicolumn{2}{|c|}{$\begin{array}{c}2.5 \\
(0.301)\end{array}$} & \multicolumn{2}{|c|}{$\begin{array}{c}-1.9 \\
(0.263)\end{array}$} \\
\hline
\end{tabular}

Source: Quadros de Pessoal, 2002, 2004, 2006.

Notes: The before period considers 2002 matches; the after period considers 2004 matches. Treatment firms have 11 to 20 workers and control firms 21 to 100 workers. In columns (1) and (1'), we compute the probability that a match survives two years. The last 4 columns repeat the exercise only for fixed-term matches. In columns (2) and $\left(2^{\prime}\right)$, we compute the two-year survival probability of a fixed-term contract. In columns (3) and (3'), we compute the two-year conversion rate of fixed-term contracts into open-ended contracts. Standard errors in parentheses. 
Table 6: Quasi-experimental evidence: Difference-in-Differences

\begin{tabular}{|c|c|c|c|c|}
\hline \multirow{2}{*}{$\begin{array}{l}\text { Treatment units } \\
\text { Control units } \\
\text { Dependent variable }\end{array}$} & \multicolumn{4}{|c|}{$\begin{array}{c}\mathrm{T}:[11,20] \\
\mathrm{C}:[21,100]\end{array}$} \\
\hline & $\begin{array}{l}\text { SFTC } \\
(1)\end{array}$ & $\begin{array}{l}\text { EFTC } \\
(2)\end{array}$ & $\begin{array}{c}\text { EOEC } \\
(3)\end{array}$ & $\begin{array}{c}\text { EWT } \\
(4)\end{array}$ \\
\hline After & $\begin{array}{c}0.445 \\
(0.139)\end{array}$ & $\begin{array}{l}-1.213 \\
(0.444)\end{array}$ & $\begin{array}{l}-1.422 \\
(0.190)\end{array}$ & $\begin{array}{l}-0.622 \\
(0.211)\end{array}$ \\
\hline Treat & $\begin{array}{l}-1.180 \\
(0.232)\end{array}$ & $\begin{array}{l}-0.710 \\
(0.800)\end{array}$ & $\begin{array}{c}0.309 \\
(0.319)\end{array}$ & $\begin{array}{c}0.153 \\
(0.353)\end{array}$ \\
\hline After $\times$ Treat & $\begin{array}{c}1.629 \\
(0.182)\end{array}$ & $\begin{array}{c}1.306 \\
(0.649)\end{array}$ & $\begin{array}{l}-0.105 \\
(0.250)\end{array}$ & $\begin{array}{c}0.292 \\
(0.277)\end{array}$ \\
\hline Control variables & \multicolumn{4}{|c|}{ - Yes. See notes - } \\
\hline Average of dependent variable & 28.2 & 34.7 & 12.4 & 24.6 \\
\hline \multicolumn{4}{|l|}{ Number of observations } & 45876 \\
\hline \multicolumn{5}{|l|}{ Before } \\
\hline Treatment & 14170 & 6030 & 13396 & 14170 \\
\hline Control & 11877 & 7138 & 11236 & 11877 \\
\hline \multicolumn{5}{|l|}{ After } \\
\hline Treatment & 81439 & 41871 & 76779 & 81439 \\
\hline Control & 73645 & 52729 & 69844 & 73645 \\
\hline Total & 181131 & 107768 & 171255 & 181131 \\
\hline
\end{tabular}

Notes: Standard errors in parentheses from firm fixed effects estimates. SFTC stands for the share of fixed-term contracts (in \%); EFTC stands for excess worker turnover among fixed-term contracts (in \%); EOEC stands for excess worker turnover among open-ended contracts (in \%); and EWT stands for excess worker turnover (in \%) among all workers. The "before" period corresponds to 2003 and the "after" period to 2004-2008. For each period, a treatment firm has 11 to 20 workers and a control firm has 21 to 100 workers. The control variables included in the regressions are: (i) Log base wage; (ii) Blue-collar workers (in \%); (iii) Educational level, percentage of workers with: 9 or less years or college (10-12 years omitted); (iv) Females (in \%); (v) Immigrants (in \%) (vi); Log firm size (average number of workers); (vii) Firm age (in years) dummies: $2,3, \ldots, 10$ years, 11-15 years, and 16-20 years (21 or more years omitted); (viii) Workforce average age (in years) dummies: $15-30,31-40$, and $41-45$ (46 or more years omitted); (ix) Workforce average tenure (in months) dummies: 1-36, 37-60, and 61-120 (121 or more months omitted); (x) Expanding and contracting employment dummies (stable employment omitted). 
Table 7: Quasi-experimental evidence: Endogeneity of treatment responses

\begin{tabular}{|c|c|c|c|c|c|c|c|c|c|}
\hline $\begin{array}{l}\text { Treatment assignment } \\
\text { Treatment units } \\
\text { Control units }\end{array}$ & \multicolumn{3}{|c|}{$\begin{array}{c}\text { In 'before' period } \\
\mathrm{T}:[11,20] \\
\mathrm{C}:[21,100]\end{array}$} & \multicolumn{3}{|c|}{$\begin{array}{c}\text { Always the same } \\
\text { T:[11,20] } \\
\text { C: }[21,100]\end{array}$} & \multicolumn{3}{|c|}{$\begin{array}{c}\text { Period-by-period } \\
\text { T: }[13,17] \\
\text { C: }[26,100]\end{array}$} \\
\hline Dependent variable & $\begin{array}{l}\text { SFTC } \\
\quad(1)\end{array}$ & $\begin{array}{l}\text { EFTC } \\
(2)\end{array}$ & $\begin{array}{c}\text { EOEC } \\
(3)\end{array}$ & $\begin{array}{l}\text { SFTC } \\
(4)\end{array}$ & $\begin{array}{l}\text { EFTC } \\
(5)\end{array}$ & $\begin{array}{l}\text { EOEC } \\
(6)\end{array}$ & $\begin{array}{l}\text { SFTC } \\
\quad(7)\end{array}$ & $\begin{array}{l}\text { EFTC } \\
(8)\end{array}$ & $\begin{array}{c}\text { EOEC } \\
(9)\end{array}$ \\
\hline After & $\begin{array}{c}0.305 \\
(0.140)\end{array}$ & $\begin{array}{l}-1.350 \\
(0.440)\end{array}$ & $\begin{array}{l}-1.371 \\
(0.185)\end{array}$ & $\begin{array}{c}0.057 \\
(0.153)\end{array}$ & $\begin{array}{l}-1.709 \\
(0.483)\end{array}$ & $\begin{array}{l}-1.412 \\
(0.210)\end{array}$ & $\begin{array}{c}0.507 \\
(0.140)\end{array}$ & $\begin{array}{l}-1.178 \\
(0.446)\end{array}$ & $\begin{array}{l}-1.394 \\
(0.188)\end{array}$ \\
\hline Treat & . & . & . & . & . & . & $\begin{array}{l}-1.657 \\
(0.254)\end{array}$ & $\begin{array}{l}-1.344 \\
(0.873)\end{array}$ & $\begin{array}{c}0.147 \\
(0.342)\end{array}$ \\
\hline After $\times$ Treat & $\begin{array}{c}1.782 \\
(0.178)\end{array}$ & $\begin{array}{c}1.278 \\
(0.620)\end{array}$ & $\begin{array}{l}-0.173 \\
(0.236)\end{array}$ & $\begin{array}{c}2.083 \\
(0.198)\end{array}$ & $\begin{array}{c}2.145 \\
(0.723)\end{array}$ & $\begin{array}{l}-0.036 \\
(0.272)\end{array}$ & $\begin{array}{l}1.805 \\
(0.202)\end{array}$ & $\begin{array}{c}1.264 \\
(0.724)\end{array}$ & $\begin{array}{l}-0.052 \\
(0.272)\end{array}$ \\
\hline Control variables & \multicolumn{9}{|c|}{ - Yes. See Table 6 - } \\
\hline $\begin{array}{l}\text { Avg. dep. variable } \\
\text { No. observations }\end{array}$ & $\begin{array}{c}25.6 \\
157446\end{array}$ & $\begin{array}{c}31.2 \\
90436\end{array}$ & $\begin{array}{c}12.3 \\
151452\end{array}$ & $\begin{array}{c}28.8 \\
142636\end{array}$ & $\begin{array}{c}35.5 \\
84519\end{array}$ & $\begin{array}{c}12.3 \\
135325\end{array}$ & $\begin{array}{c}25.6 \\
153662\end{array}$ & $\begin{array}{c}33.6 \\
95179\end{array}$ & $\begin{array}{c}11.8 \\
145438\end{array}$ \\
\hline $\begin{array}{l}\text { Notes: Standard error } \\
\text { contracts (in \%); EFT } \\
\text { contracts and open-end } \\
\text { before period and kept } \\
\text { we consider only firms } \\
\text { by considering treatme } \\
100 \text { workers. In colum } \\
\text { particular, in the befor } \\
\text { workers are also exclud }\end{array}$ & $\begin{array}{l}\text { contrac } \\
\text { e same e } \\
\text { at never } \\
\text { firms th } \\
(7)-(9) \text {, } \\
\text { eriod, fir }\end{array}$ & $\begin{array}{l}\text { (in \%). } \\
\text { h year th } \\
\text { anged tre } \\
\text { always } \\
\text { ms that } \\
\text { s with } 18\end{array}$ & $\begin{array}{l}\text { n column } \\
\text { oughout } \\
\text { tment st } \\
\text { ad } 11 \text { to } \\
\text { ustered a }\end{array}$ & $\begin{array}{l}\text { after p } \\
\text { workers } \\
\text { und the }\end{array}$ & $\begin{array}{l}\text { od regar } \\
\text { he entire } \\
\text { nd simil } \\
\text { ze thresl }\end{array}$ & $\begin{array}{l}\text { ess of th } \\
\text { ampling } \\
\text { ly contr }\end{array}$ & $\begin{array}{l}\text { ol statu } \\
\text { rm size. } \\
\text { ciod, i.e } \\
\text { irms th }\end{array}$ & $\begin{array}{l}\text { are defi } \\
\text { colum } \\
\text { t exclud } \\
\text { always }\end{array}$ & $\begin{array}{l}\text { d-term } \\
\text { d-term } \\
\text { in the } \\
(4)-(6) \\
\text { movers } \\
\text { d } 21 \text { to } \\
\text { ple. In } \\
1 \text { or } 12\end{array}$ \\
\hline
\end{tabular}

Table 8: Rates of excess worker turnover: Fixed effects estimation

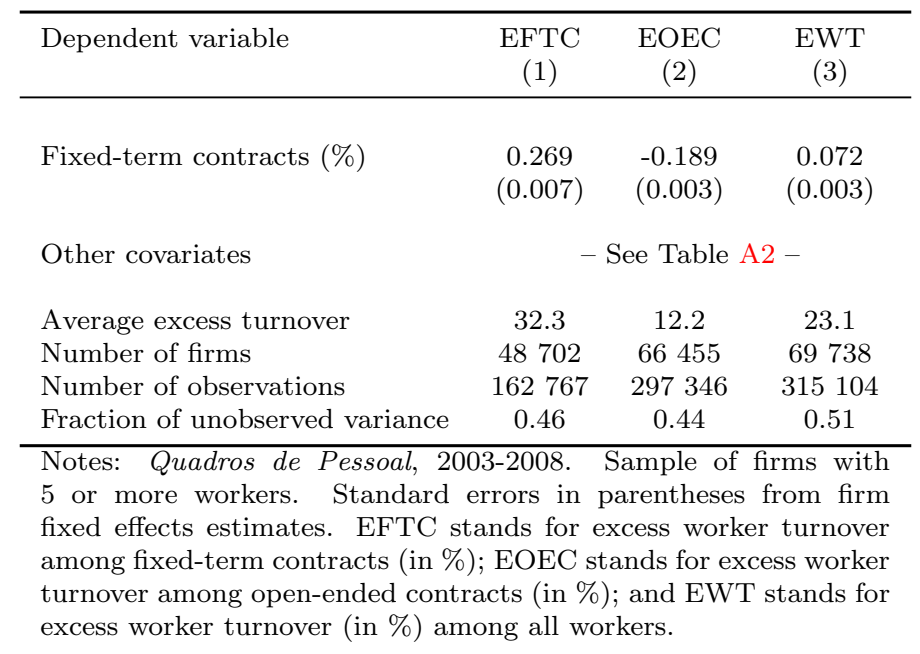




\section{A Appendix}

Table A1: Summary statistics: Firm-level data, 2003-2008

\begin{tabular}{|c|c|c|}
\hline Variable (firm level) & Mean & $\begin{array}{c}\text { Std. } \\
\text { Deviation }\end{array}$ \\
\hline Fixed-term contracts per firm (in \%) & 28.2 & 27.93 \\
\hline Total excess worker turnover (in \%) & 24.6 & 25.71 \\
\hline \multicolumn{3}{|l|}{ Excess worker turnover by contract type: } \\
\hline Fixed-term contract & 34.7 & 36.89 \\
\hline Open-ended contract & 12.4 & 19.75 \\
\hline (Log) base wage & 6.39 & 0.38 \\
\hline Blue-collar workers (in \%) & 36.3 & 25.19 \\
\hline \multicolumn{3}{|c|}{ Educational level, percentage of workers with: } \\
\hline 9 or less years & 69.9 & 27.31 \\
\hline $10-12$ years & 19.7 & 18.97 \\
\hline College & 10.4 & 16.56 \\
\hline Females (in \%) & 42.7 & 32.67 \\
\hline Immigrants (in \%) & 5.6 & 13.23 \\
\hline Firm size (average number of workers) & 27.1 & 18.86 \\
\hline Firm age (in years) & 21.2 & 25.47 \\
\hline Workforce average age (in years) & 37.7 & 5.28 \\
\hline Workforce average tenure (in months) & 79.8 & 57.08 \\
\hline Worker-firm matches (2003-2008) & \multicolumn{2}{|c|}{4903529} \\
\hline Number of firms & \multicolumn{2}{|c|}{45876} \\
\hline \multicolumn{3}{|l|}{ Number of observations (firm $\times$ year) } \\
\hline \multicolumn{3}{|l|}{ Before } \\
\hline Treatment & \multicolumn{2}{|c|}{14170} \\
\hline Control & \multicolumn{2}{|c|}{11877} \\
\hline \multicolumn{3}{|l|}{ After } \\
\hline Treatment & \multicolumn{2}{|c|}{81439} \\
\hline Control & \multicolumn{2}{|c|}{73645} \\
\hline Total & \multicolumn{2}{|c|}{181131} \\
\hline
\end{tabular}


Table A2: Rates of excess worker turnover: Fixed effects estimation (unabridged version)

\begin{tabular}{|c|c|c|c|}
\hline Dependent variable & $\begin{array}{c}\text { EFTC } \\
(1)\end{array}$ & $\begin{array}{c}\text { EOEC } \\
(2)\end{array}$ & $\begin{array}{c}\text { EWT } \\
(3)\end{array}$ \\
\hline Fixed-term contracts $(\%)$ & $\begin{array}{c}0.269 \\
(0.007)\end{array}$ & $\begin{array}{l}-0.189 \\
(0.003)\end{array}$ & $\begin{array}{c}0.072 \\
(0.003)\end{array}$ \\
\hline Average (log) base wage & $\begin{array}{c}-10.481 \\
(1.126)\end{array}$ & $\begin{array}{c}-1.988 \\
(0.461)\end{array}$ & $\begin{array}{c}-6.671 \\
(0.506)\end{array}$ \\
\hline Blue collar (\%) & $\begin{array}{c}0.056 \\
(0.009)\end{array}$ & $\begin{array}{c}0.003 \\
(0.004)\end{array}$ & $\begin{array}{c}0.012 \\
(0.004)\end{array}$ \\
\hline \multicolumn{4}{|l|}{ Educational shares (\%): } \\
\hline 9 or less years & $\begin{array}{c}0.035 \\
(0.016)\end{array}$ & $\begin{array}{c}0.004 \\
(0.007)\end{array}$ & $\begin{array}{c}0.019 \\
(0.007)\end{array}$ \\
\hline College or more & $\begin{array}{c}0.152 \\
(0.026)\end{array}$ & $\begin{array}{c}0.051 \\
(0.011)\end{array}$ & $\begin{array}{c}0.081 \\
(0.012)\end{array}$ \\
\hline Female (\%) & $\begin{array}{l}-0.079 \\
(0.019)\end{array}$ & $\begin{array}{c}-0.024 \\
(0.008)\end{array}$ & $\begin{array}{c}-0.041 \\
(0.008)\end{array}$ \\
\hline Immigrants (\%) & $\begin{array}{c}0.046 \\
(0.020)\end{array}$ & $\begin{array}{l}-0.024 \\
(0.010)\end{array}$ & $\begin{array}{c}0.028 \\
(0.010)\end{array}$ \\
\hline Firm size (log) & $\begin{array}{l}23.315 \\
(1.640)\end{array}$ & $\begin{array}{c}7.095 \\
(0.722)\end{array}$ & $\begin{array}{c}6.850 \\
(0.789)\end{array}$ \\
\hline Firm size (log) squared & $\begin{array}{c}-1.566 \\
(0.237)\end{array}$ & $\begin{array}{l}-0.531 \\
(0.114)\end{array}$ & $\begin{array}{l}-0.053 \\
(0.125)\end{array}$ \\
\hline \multicolumn{4}{|l|}{ Firm age (in years): } \\
\hline 2 & $\begin{array}{c}2.094 \\
(1.745)\end{array}$ & $\begin{array}{c}3.353 \\
(0.739)\end{array}$ & $\begin{array}{c}2.617 \\
(0.809)\end{array}$ \\
\hline 3 & $\begin{array}{c}1.719 \\
(1.576)\end{array}$ & $\begin{array}{c}2.281 \\
(0.665)\end{array}$ & $\begin{array}{c}3.165 \\
(0.735)\end{array}$ \\
\hline 4 & $\begin{array}{c}-0.434 \\
(1.482)\end{array}$ & $\begin{array}{c}1.866 \\
(0.628)\end{array}$ & $\begin{array}{c}1.517 \\
(0.696)\end{array}$ \\
\hline 5 & $\begin{array}{c}-0.832 \\
(1.395)\end{array}$ & $\begin{array}{c}1.140 \\
(0.589)\end{array}$ & $\begin{array}{c}0.204 \\
(0.656)\end{array}$ \\
\hline 6 & $\begin{array}{c}-1.555 \\
(1.307)\end{array}$ & $\begin{array}{c}0.988 \\
(0.551)\end{array}$ & $\begin{array}{c}0.361 \\
(0.615)\end{array}$ \\
\hline 7 & $\begin{array}{c}-1.828 \\
(1.223)\end{array}$ & $\begin{array}{c}0.708 \\
(0.516)\end{array}$ & $\begin{array}{c}0.413 \\
(0.576)\end{array}$ \\
\hline 8 & $\begin{array}{c}-1.101 \\
(1.146)\end{array}$ & $\begin{array}{c}0.545 \\
(0.483)\end{array}$ & $\begin{array}{c}0.349 \\
(0.540)\end{array}$ \\
\hline 9 & $\begin{array}{c}-0.875 \\
(1.075)\end{array}$ & $\begin{array}{c}0.171 \\
(0.454)\end{array}$ & $\begin{array}{c}0.280 \\
(0.508)\end{array}$ \\
\hline 10 & $\begin{array}{c}-0.744 \\
(1.012)\end{array}$ & $\begin{array}{c}0.729 \\
(0.428)\end{array}$ & $\begin{array}{c}0.309 \\
(0.480)\end{array}$ \\
\hline$[11,15]$ & $\begin{array}{l}-0.885 \\
(0.789)\end{array}$ & $\begin{array}{c}0.352 \\
(0.328)\end{array}$ & $\begin{array}{c}0.022 \\
(0.369)\end{array}$ \\
\hline$[16,20]$ & $\begin{array}{l}-0.147 \\
(0.548)\end{array}$ & $\begin{array}{c}0.142 \\
(0.225)\end{array}$ & $\begin{array}{l}-0.017 \\
(0.253)\end{array}$ \\
\hline Expansion period & $\begin{array}{l}-5.359 \\
(0.257)\end{array}$ & $\begin{array}{c}0.780 \\
(0.103)\end{array}$ & $\begin{array}{l}-1.081 \\
(0.115)\end{array}$ \\
\hline Contraction period & $\begin{array}{c}-0.723 \\
(0.260)\end{array}$ & $\begin{array}{l}-0.224 \\
(0.102)\end{array}$ & $\begin{array}{l}-1.782 \\
(0.115)\end{array}$ \\
\hline Other covariates & & s. See no & s. - \\
\hline Average excess turnover & 32.3 & 12.2 & 23.1 \\
\hline Number of firms & 48702 & 66455 & 69738 \\
\hline Number of observations & 162767 & 297346 & 315104 \\
\hline Fraction of unobserved variance & 0.46 & 0.44 & 0.51 \\
\hline
\end{tabular}

